\title{
Setting the stage for corporate headquarters: a technological explanation for the rise of modern industrial corporations
}

\author{
Carliss Y. Baldwin
}

$\overline{\text { Correspondence: cbaldwin@hbs.edu }}$ Harvard Business School, Boston, MA, USA

\begin{abstract}
This paper combines theories of organizational design with theories of production to provide a novel perspective, which helps explain the technological forces that led to the rise of vertically integrated "modern" corporations in the late nineteenth and early twentieth centuries. I describe the technology of a flow process with bottlenecks and show how this technology rewards unified governance, a hierarchical organization structure, and the use of direct authority. These properties in turn became the organizational hallmarks of "modern" industrial corporations with central corporate headquarters.
\end{abstract}

\section{Introduction}

Throughout most of the nineteenth century, large industrial holdings were loose amalgamations of business units with little or no central coordination. For example, Henry du Pont, president of the Du Pont Company and a majority shareholder in a number of other powder companies, ran his properties from a one-room office where he "wrote all of the business correspondence himself in long hand" (Chandler Jr 1962: 55). The businesses were managed as independent enterprises with loose control and essentially no coordination. Henry's great-nephew Pierre S. du Pont commented, "I think the old company had a very slim idea of the property they possess" (Chandler Jr 1962: 55).

However, beginning around 1870, new technologies-automated machinery, fast reliable transportation via railroads, the telegraph, and the telephone-combined with population growth to create opportunities to integrate the manufacturing, marketing, and distribution of many goods within large-scale, efficient flow processes. The rationalization of du Pont's far-flung holdings was undertaken by the cousins, Alfred, Pierre, and Coleman du Pont, between 1903 and 1908. The cousins' goal was to combine the functions of buying, manufacturing, shipping, and selling explosive powder under one management that would run the operations for maximum efficiency. To this end, the du Ponts created a number of new administrative departments dedicated to manufacturing, marketing, engineering, transportation, purchasing, and R\&D. To

(c) The Author(s). 2019 Open Access This article is distributed under the terms of the Creative Commons Attribution 4.0 International License (http://creativecommons.org/licenses/by/4.0/), which permits unrestricted use, distribution, and reproduction in any medium, provided you give appropriate credit to the original author(s) and the source, provide a link to the Creative Commons license, and indicate if changes were made. 
promote close coordination among departments, the department heads and their top staff were brought together in a new 11-story office building in central Wilmington. A large building full of salaried managers thus replaced Henry du Pont's one-room office (Chandler Jr 1962: 56-57).

This paper combines theories of organization design and theories of production to explain the technological forces that led to the rise of centrally managed, vertically integrated corporations like DuPont in the late nineteenth century and early twentieth century. Alfred Chandler called these firms "modern industrial corporations" (Chandler Jr 1962: 56-57). These companies were run by salaried managers and organized as bureaucratic hierarchies (Chandler Jr 1962, 1977, 1990). At the apex of the hierarchy were top executives, the heads of departments, and the corporate headquarters staff. For most of the twentieth century, these companies epitomized "big business" and "high technology" (Schumpeter 1942; Kaplan 1964; Galbraith 1967; ServanSchreiber1968; Rosenberg and Birdzell Jr 2008; Hounshell 1985; Drucker 1993; Marx 1994; Baumol 2002; Landes, 2003; Fukuyama 1995).

The characteristics commonly associated with so-called "modern corporations" are (1) unified governance, (2) a managerial hierarchy, and (3) the use of direct authority. Unified governance means that the enterprise operates as a single entity under one management. Ultimate authority is vested in a single person or a Board of Directors, although decisions may be delegated to employees, partners, and contractors. Corporations, proprietorships, and partnerships have unified governance under the law. Trusts, consortia, alliance networks, and business ecosystems do not. Economists and business historians often refer to unified governance as "vertical integration." However, vertical integration may simply refer to the common ownership of different stages of production. To avoid confusion, I define unified governance as common ownership combined with active, centralized coordination of different parts of a technical process. Henry du Pont owned many powder companies, but he did not attempt to bring them under unified governance. In addition to having unified governance, in modern corporations, information and decision rights are generally (but not always) organized as a hierarchy with subordinates reporting to superiors in a chain leading to the Board of Directors. Finally, employees in modern corporations are subject to direct authority. Within some pre-established "area of acceptance," subordinates must obey the direct orders of their superiors (Simon 1951). Failure to obey an order is grounds for discipline or firing. Although these three properties-unified governance, hierarchical organization, and use of direct authority-are often found together, they are conceptually distinct. Each one can be present without the other two.

In this paper, I build on prior work examining the provenance of the multi-divisional firm (M-form). Historical perspectives, such as present study, enrich our understanding of the emergence and evolution of large corporations (Birkinshaw 2018; da Silva et al. 2018) and corporate headquarters (Menz et al. 2015). However, rather than focus on the M-form's allocative efficiencies (e.g., Chandler Jr 1962) or implicit contracts (Williamson 1985), I shall argue that a particular set of technologies reward organizations characterized by unified governance, hierarchy, and direct authority. The technologies can be grouped under the heading "rationalized flow" or "integrated step" processes. (I will use these terms interchangeably.) At the end of the nineteenth century, because of the growth of automated factories and the reduction in rail transportation costs, the economic 
rewards that could be obtained by rationalizing large-scale flows of goods were enormous. However, flow technologies did not run themselves: they contained bottlenecks that required active managerial supervision, frequent intervention, and central coordination (Chandler Jr 1986). The need to manage bottlenecks in turn provided strong inducements to design organizations subject to strong central control and direct authority. Highlighting and elaborating this mechanism is a key contribution of the paper.

The plan of the paper is the following. First, I describe the technology of flow rationalization. I model the technology as a series of essential steps, subject to capacity constraints in the form of bottlenecks. I explain how systematic management aimed at eliminating bottlenecks is critical to the efficiency of flow technologies. Second, I go on to argue that unified governance, hierarchical organization structure, and direct authority can be used to make flow processes more efficient. Finally, modern corporation law, as it developed in the late nineteenth century, provided legal support for the properties demanded by flow technologies. By 1917, virtually all large enterprises had become corporations. And in each of these corporations, a central corporate headquarters sat at the apex of the corporate hierarchy managing the flows of goods and information mandated by technology.

\section{Innovations in the industrial organizations}

\section{Flow technologies and systematic management}

From 1750 to 1920 approximately, the movement of industrial organization was towards higher levels of centralization supporting ever-higher levels of output. Production tasks came to be located in factories, which replaced the older "putting out" of household production. In factories, technical steps were subdivided and human strength augmented by powered machinery. Even though Adam Smith praised the productivity gains of a simple division of labor, the need to be near a central power source seems to have been the decisive factor behind the rise of factories in England in the eighteenth century (Landes 1998: 209).

In the decades following 1750, machines got better, and sources of power, including water and steam engines, became more efficient. Larger and more powerful machines were inserted into production processes that were divided into finer steps. Around 1850, the baton of industrial innovation passed from Great Britain to the USA (Hounshell 1985: 17-25). The American railroad system made the Midwest and far West accessible to Eastern producers. Transportation costs and shipment times dropped precipitously so that many local markets could now be served by distant companies (Chandler Jr 1977; Fields 2004). The so-called American system of manufacturing, which was based on very fine divisions of labor and specialized machinery, permitted single factories to produce goods in volumes never seen before.

However, as the tasks became more sub-divided and the intermediate steps more numerous, production flow systems, like that at the Singer Sewing Machine Co., spun out of control.

The problem was a gradual breakdown of the integration of workflow at the lower levels of the company and a concordant deterioration in the ability of top executives to control work lower in the company hierarchy (Litterer 1963: 373).

The response was a movement towards "systematic management" aimed at rationalizing production within factories (Kendall 1912). The systematizers, including Slater 
Lewis, Henry Metcalf, Alexander Church, H.M. Norris, and John Tregoing, invented production control systems, inventory control systems, and cost accounting systems and implemented them at a number of firms (Litterer 1963). Frederick W. Taylor extended their work by incorporating detailed time studies and advocating a "differential piece rate" form of compensation. He became a famous advocate of what he called "scientific management."

These organizational innovations aimed at controlling and coordinating the flow of production through a factory increased output, but also took away the workers' autonomy. Rather than the foreman or worker deciding what to make and what supplies to use, control and scheduling functions were performed by specialized staff, including stock clerks (to control inventory), production control clerks (to keep track of orders), and time keepers (to measure work flow through various tasks) (Litterer 1963: 387). The methods and principles developed by the systematizers allowed complex factory systems to operate at ever-higher levels of output (scale) without collapsing into chaos.

For example, in oil, the throughput of the largest refineries increased from 500 to 6500 barrels per day between 1866 and 1879 and increases continued through 1900 (Chandler Jr 1985). In steel, the production of large blast furnaces increased from about 6000 tons per year in the 1860s to over 100,000 tons a year in the late 1890s (Temin 1964). Rolling mills exhibited an even higher rate of growth in throughput: in 1850, a typical mill might produce 3000 tons a year, while in 1900, a large rolling mill's output was 3000 tons a day, or approximately 900,000 tons a year (Temin 1964; Popplewell 1906). A single Bonsack machine could roll as many cigarettes as 50 skilled workers at a fraction of the cost. ${ }^{2}$ The output of Singer sewing machines was less than 1000 per year in 1856; by 1880, two factories produced 500,000 machines per year (Hounshell 1985).

As factories became larger, it became necessary to coordinate not only flows within factories but also flows of supplies and flows of finished goods through transportation networks and marketing systems to final customers. Systematic management was used to rationalize these flows as well. Companies built information systems to predict final consumer demand and to track goods that were in transit or in warehouses.

A flow of tasks and transfers is a necessary corollary of a division of labor. What was previously undivided work performed by one person becomes a set of tasks performed by different people and a series of transfers between them (Smith 1994). Below I describe why it is necessary to rationalize flow processes, and then explore how the technology of flow production shaped the boundaries and internal structure of organizations.

\section{A model of production based on flow}

Let me model a flow production process as a series of steps that begins by taking in raw materials, fabricates intermediate components, combines components into a finished product, and then transports and sells the product to the final customer. The steps take place in a sequence, although not always a strict sequence. For example,

\footnotetext{
${ }^{1}$ Taylor was the most visible and controversial proponent of efficiency and flow rationalization, but the systematizing movement started well before his time. Most of the important innovations were made by others (Nelson 1974).

${ }^{2}$ http://www.learnnc.org/lp/editions/nchist-newsouth/4705 (accessed June 13, 2016).
} 
intermediate components can be produced in parallel and then assembled. Ingots of metal may be formed in the same furnace, but then sent to different rolling mills to be fabricated into finished products. In a "job shop," the sequence of steps may vary from job to job. Steps are essential to the model, sequence is not.

When a single factory makes many products, scheduling the flow of production is very difficult. When many steps are involved, it becomes impossible to keep all machinery and workers fully utilized at all times. Thus, it is not surprising that, as the use of expensive machinery increased, many firms reduced the breadth of their product lines.

At one time a metal working factory would be willing to make pumps, steam engines, farm implements, tools, locomotives, in brief, just about anything in metal their craftsmen could handle. By the end of the Civil War a number of specialized manufacturers emerged who made just pumps, or locomotives or machine tools (Litterer 1963: 467).

The critical property of a series of steps aimed at making a particular product is that all steps must take place in strict proportion. Let us think of the productive steps as a set of functional complements (Baldwin 2018b):

$$
s_{1} \square s_{2} \square \ldots s_{i} \square s_{j} \ldots \square s_{N-1} \square s_{N}=S
$$

Here $s_{i}$ denotes a single step in the production process and $S$ the finished good, which might be a sewing machine. The symbol $\square$ signifies that the steps are strong complements, i.e., if any step is left out, the entire effort fails. ${ }^{3}$ Within each step, a particular technical procedure is carried out and the intermediate good is then passed to another step. ${ }^{4}$ Each step is performed by a worker in conjunction with appropriate materials and machinery.

The steps are tied together by more than functional complementarity. Each has a certain capacity, that is, a maximum number of units that can be processed per unit of time. Because all steps are necessary to make the final good, the production capacity of the entire system in a given time interval equals the minimum of the capacities of the separate steps:

$$
Q_{\min }=\min \left(q_{1}, \ldots, q_{i}, q_{j}, \ldots, q_{N}\right)
$$

Here $Q_{\min }$ denotes the capacity of the system, and $q_{i}$ denotes the capacity of step $s_{i}$. In general, individual $q_{i}^{\prime}$ s are stochastic, that is, the output of each step in each time interval may vary because of unknown causes. Such variation can be addressed through systematic diagnosis and problem-solving.

The step with the least capacity (in any interval) is known as the production bottleneck:

Production Bottleneck $\equiv$ step such that $q_{B}=\min \left(q_{1}, \ldots, q_{N}\right)$.

\footnotetext{
${ }^{3}$ Strong complements are also called "unique" or "perfect" complements. See, for example, Hart and Moore (1990); Jacobides et al. (2018); Baldwin (2018a).

${ }^{4}$ The step index (subscript) is arbitrary and may not correspond to the order of the steps. What is critical is that all steps must be performed to obtain the finished product.
} 
As with all bottlenecks, production bottlenecks are important targets of managerial attention and investment (Baldwin 2018c).

\section{Properties of stochastic step processes}

Two important properties of stochastic multi-step processes can be shown to hold for any set of underlying distributions. They are:

Proposition 1.In the absence of systematic management, expected system capacity decreases with the number of steps in the process. In other words, adding steps by subdividing work without attending to bottlenecks is likely to make overall performance worse. $^{5}$

Proposition 2.In the absence of systematic management, expected system capacity decreases with the random variability of any step. Thus adding random variation to any step is also likely to make overall performance worse. ${ }^{6}$

Proposition 1 implies that the division of labor is a two-edged sword. On the one hand, the narrowing of tasks combined with special-purpose, powered machinery can greatly increase the capacity of an individual step. However, the process as a whole is hostage to the least-efficient step-the production bottleneck. Especially in systems using novel technology and/or experiencing rapid growth, adding more steps to the process has the potential to decrease the capacity of the entire system in the short run.

The solution to this conundrum, of course, is not to take the capacity of any step as a given. Instead, managers must proactively seek to identify production bottlenecks and increase their capacity. This means first studying the process from start to finish. In the nineteenth and early twentieth centuries, the problem was addressed by men armed with stopwatches, clipboards, and slide rules. Firms began to hire special timekeepers, process engineers, and ultimately planners and schedulers to observe the workers and machines, analyze the data, and implement flow-enhancing changes in the technical design of the systems. ${ }^{7}$

These men (for most were men) inserted a new layer of specialized workers between the top managers of a factory and the foremen and workers who handled material and machines. The new layer of staff dealt with information-orders, schedules, inventory,

\footnotetext{
${ }^{5}$ Proof of Proposition 1. Consider one realization of a process with $N$ steps. The realization results in a capacity for the system as a whole, $\hat{Q}$, that is the minimum of the realizations of the $N$ steps: $\hat{Q}=\min \left(\hat{q}_{1}, \ldots\right.$, $\left.\hat{q}_{N}\right)$.Now consider adding a step to the process. The new step has a cumulative distribution function $F_{N+1}\left(q_{N}+1\right)$. This function does not have to be known to the analyst. Let the support of $F_{N+1}$ be $\left(q_{\text {min }}\right.$ $\left.q_{\max }\right)$. If $q_{\min }<\hat{Q}$, then adding step $N+1$ diminishes the capacity of the system with probability $F_{N+1}(\hat{Q})$, which is greater than zero. If $\hat{Q} \leq q_{\min }$, then adding the step leaves system capacity unchanged. Thus, adding a step weakly decreases the expected capacity of the system as a whole. QED.

${ }^{6}$ Proof of Proposition 2. Consistent with Rothschild and Stiglitz (1970), I define increasing variability (risk) as the addition of a mean preserving spread to a given probability distribution. Consider again a process of $N$ steps that has a realized capacity of $\hat{Q}=\min \left(\hat{q}_{1}, \ldots, \hat{q}_{N}\right)$. The impact of the $N+1$ step on the capacity of the system is: $P\left(\tilde{q}_{N+1}\right)={ }_{0} \hat{q}_{N+1}-\hat{Q} \quad \begin{gathered}\text { if } \hat{q}_{N+1}<\hat{Q} \\ \text { otherwise }\end{gathered} . P(\cdot)$ is a concave function, thus, as demonstrated by Rothschild and Stiglitz:EP(Y) $\leq E P(X)$ if $Y=X+$ mean preserving spread. Therefore, increasing the variability of the $N+1$ st step weakly reduces the expected value of system capacity. (The reduction is strong if the lower bound of the support of $Y$ is less than $\hat{Q}$.) This result holds (1) for any focal step in the process and (2) for any realization of $\hat{Q}$ for the $N$ steps that are not the focal step. $Q E D$.

${ }^{7}$ Not everyone saw value in these procedures. The owners of smaller shops, in particular, perceived the methods to be "theoretical and highly impractical," leading only to "extra clerks." One foreman said of the systematizers: "they had every man in the place running around with a pencil over his ear, and we did not get the work done" (Shenhav 1995, p. 565).
} 
plans - which was used to eliminate bottlenecks and rationalize flow within and beyond the factory. The hiring of these individuals signaled the emergence of a multilevel, multi-function managerial hierarchy. These clerks were the precursors of a new class of middle managers in what became large corporate bureaucracies (Litterer 1963; Chandler Jr 1977).

According to Proposition 1, a random negative draw in any step may turn that step into a bottleneck. Proposition 2 then states that the wider the potential variation, the more damage a random bottleneck can do to the performance of system as a whole. Uncontrolled variation is "the enemy" in a multi-step production process subject to capacity constraints.

It follows that there is real value to controlling each step to reduce its intrinsic variation. ${ }^{8}$ In effect, the technical system creates an environment in which extreme risk aversion pays. This is the essential insight behind the so-called "six-sigma" approach to process improvement: the process performs as predicted $99.99966 \%$ of the time (Harry and Schroeder 2005).

If particular steps cannot be controlled beyond certain limits, then there must be buffers between them. If the individual step-capacities in each small time interval are independent, then the variance of the sequence will decrease as the time interval grows longer. In this fashion, buffers can absorb the variability of individual steps and the law of large numbers can work to make the throughput of the system more consistent and predictable. Thus, buffering is a way to reduce effective step variability and increase the overall capacity of the system.

However, buffering comes at a cost. First, there is the direct cost of the inventory itself. Second, the use of buffers makes it unnecessary to study each step in detail to reduce its variation through better design of the actual workflow. If one can reduce step variation directly, then buffering inventories can be eliminated. This is the essential insight behind Toyota's identification of buffers as source of "waste" (muda) in a production system.

In a multi-step flow process, technology operating through the "min" function ties the steps together in a particular way so that any step can constrain the whole system. Interdependence among steps is what makes variability costly for the process as a whole. To see this, suppose each step made a completely independent contribution to the value of the whole. Then, if one step had poor throughput in a given interval, the other steps would not be affected. Over time, each step would contribute an average amount to the process as a whole, and the output of the whole would be the sum of these averages.

\section{Elimination of bottlenecks}

\section{Unified governance (vertical integration)}

The presence of bottlenecks scattered through the steps of a process creates the need for centralized coordination and integrated decision-making within the boundaries of a single firm. In the absence of bottlenecks, different parts of a step process can be carried out with little or no loss of value by two or more separate firms. To see this, let us imagine a production process with labor-saving capital and a growing market, but no

${ }^{8}$ Jaikumar and Bohn (1986) make a similar argument. 
bottlenecks. Consider two firms, Upstream and Downstream. Upstream is responsible for production and can make labor-saving capital investments. Downstream purchases Upstream's output and is responsible for distribution and marketing: it can make investments that increase the size of the market. By assumption, there are no bottlenecks: either type of firm can increase its capacity without limit. ${ }^{9}$

Now suppose Downstream has the opportunity to invest in advertising to increase the size of its market. In the absence of bottlenecks, it will increase the quantity of goods ordered from its Upstream supplier. Thus, the Upstream firm will benefit from Downstream's market-expanding investment (an externality). The higher quantities ordered will then increase the value to Upstream of cost-saving capital investment. Once the investment has been made, lower variable costs will lead Upstream to reduce the price of its intermediate good. Thus, Downstream will benefit from Upstream's cost-reducing investment (another externality). It will then have incentive to invest again to expand the market.

In effect, Upstream and Downstream firms are in a symbiotic relationship, but they can coordinate their actions in the market, via prices charged and quantities ordered. Even though their choices are complementary, ${ }^{10}$ market signals are sufficient to push both firms' investments in the "right" direction. ${ }^{11}$

The presence of bottlenecks scattered among the steps causes decentralized decisionmaking to break down and thus creates a "demand" to place all steps in a single firm under unified governance. For example, suppose Downstream sees an opportunity to increase the size of its market, but Upstream faces a bottleneck in production. Upstream will then not be able to increase its production to meet Downstream's new demand, and Downstream's investment will not pay off. Symmetrically, if Upstream invests in labor-saving equipment and Downstream faces bottlenecks in distribution, then Downstream will not increase the quantity of goods ordered. Upstream will gain from lower costs, but will not be able to grow, reducing its return on investment.

If one side attempts to contract with the other to fix its bottleneck, a classic holdup problem ensues. The bottleneck, by definition, constrains the throughput of the entire process. The owner of the bottleneck is thus in a position of great bargaining power vis-a-vis the owner(s) of the rest of the process. He or she has control of a unique asset on which the productivity of non-bottleneck assets depends. Under the standard reasoning of transaction costs economics, the owner of the bottleneck can expect to be paid a significant percentage of the value gain to the entire process that comes from fixing the bottleneck. The expectation of holdup, in turn, reduces the value of systematic management to the owner(s) of the other steps.

In summary, separate firms carrying out interdependent step processes subject to bottlenecks have reduced incentives to invest in market-expanding or costsavingtechnologies. Even more insidious is the fact that none will have incentives to

\footnotetext{
${ }^{9}$ I assume that Upstream and Downstream's assets are not co-specialized: each has other potential trading partners and thus is not vulnerable to holdup by the other.

${ }^{10}$ Super-modular complementarity is the property that more of one action makes more of the other more valuable. Market growth and cost-reducing investments are super-modular complements: a larger market makes the lower costs more valuable and lower costs make a larger market more valuable. See Milgrom and Roberts (1990) and (1995) on the properties of super-modular functions.

${ }^{11}$ Baldwin (2018a) calls this property "distributed super-modular complementarity" (DSMC). DSMC gives rise to modular production networks and business ecosystems (Sturgeon 2002; Jacobides et al. 2018.)
} 
invest in systematic management to identify and eliminate bottlenecks in its own processes. If each is hostage to the other's bottlenecks, in equilibrium, none will invest to increase its own throughput, for such investments will be wasted. In effect, nonintegrated firms are in a classic coordination game with respect to investments in systematic management: both must invest if either is to benefit. ${ }^{12}$

Placing Upstream and Downstream's processes within a single firm under unified governance changes the incentives to address bottlenecks. Within a single firm, information can flow to a central authority who can take appropriate action without seeking permission of a third party. Bottlenecks can be addressed wherever they arise without risk of holdup. A single firm that spans all steps thus has greater incentives to invest in systematic management tools and techniques than separate firms carrying out the same step processes as independent actors pursuing their own interests.

In fact, in the late nineteenth century, across a range of industries, firms like du Pont and Singer that vertically integrated and then rationalized their flow production systems came to dominate their non-integrated rivals through a combination of rapid market expansion and impressive cost reductions. The result was the emergence of a new class of organizations, which Alfred Chandler labeled "modern industrial corporations" (Chandler Jr 1977).

\section{Hierarchical organization}

The large modern industrial corporations that emerged at the turn of the twentieth century were not only under unified governance, they were also organized in a hierarchical fashion by functional departments. Each functional group was responsible for some portion of the flow process-procurement, fabrication of parts, assembly, distribution, and marketing. Proximate units were grouped together under the supervision of a more senior official. These hierarchies generally extended from the very top of the company down to the level of front-line workers.

Viewed strictly as a means of structuring communication linkages, hierarchy is an efficient way to filter large amounts of day-to-day operational information. This was in fact the essence of James Thompson's theory of design for "boundedly rational" organizations: create groups that mirror the individual's need to communicate and coordinate actions in real time then create groups of groups according to declining interdependency. The groupings fostered timely mutual adjustments and the hierarchy served as a means of conflict resolution "with each grade in the hierarchy specializing in resolving conflicts of the grade beneath it" (Thompson 1967).

\footnotetext{
${ }^{12}$ Let $V$ denote the value of systematic management if both firms invest, and let $a$ denote the cost of such a program. Assume that $V>>a$, that is, systematic management is very profitable. The payoff matrix for the game is:With simultaneous moves, there are two equilibria: both may invest or both may not invest. However, if at the starting point of the game, neither has invested, then the game is at an equilibrium and neither will invest.
}

\begin{tabular}{llll} 
& & \multicolumn{2}{l}{ Downstream } \\
Invest & \multicolumn{1}{c}{ Don't invest } \\
\cline { 3 - 4 } Upstream & Invest & D-a, $\mathrm{V}-\mathrm{a}$ & $-\mathrm{a}, 0$ \\
\cline { 3 - 4 } & Don't invest & $0,-\mathrm{a}$ & 0,0 \\
\cline { 3 - 4 } & & &
\end{tabular}


In a flow process, the highest levels of interdependency arise between nearby steps; thus, most of the necessary communication takes place locally. In a hierarchy, only selected information gets passed up to higher levels and then possibly back down to distant groups. The whole can be coordinated by setting consistent objectives for throughput across the whole organization within a given time period.

Groups at the lowest level of the hierarchy can manage to the plan, dealing with small deviations as necessary. Thompson called this "coordination by mutual adjustment" (Thompson 1967: 56). Large deviations can be flagged and passed up to successively higher levels according to their magnitude. Such flags would cause additional problemsolving resources to be allocated to the point of disruption and could also trigger revisions in the plans of other departments. If the functional units are buffered from one another, for example, by intermediate inventories, then the effect of a disruption in one segment will be attenuated in the more distant parts of the enterprise. Thus, a hierarchy is an effective way to match the scope of communication and the scale of responses to the magnitude of random disruptions, wherever and whenever they arise.

The techniques of systematic management relied on new types of information, which had to be collected, analyzed, and transferred up, down and across the hierarchy. The clerks, who kept track of orders, throughput and inventory, plus those in charge of sending plans, updates, policies, and decisions to far-flung parts of the enterprise, were newcomers to business organizations. They did not make, assemble, transport, or sell: they directed, coordinated, analyzed, and supplied expertise to those who did. To be effective, they needed channels of communication with each other and with top managers who set goals and allocated resources. Channels of communication in those times inevitably passed through people-there were no computer-generated reports or automatic responses. Thus, the top managers of large enterprises, like generals of armies, came to be surrounded in their headquarters by a cadre of senior staff. Senior staff members supervised their own hierarchical organizations, but also consulted with one another and designed uniform policies and plans binding on the entire organization.

\section{Direct authority}

Charles Perrow has argued that there are three types of control in organizations: (1) direct, fully obtrusive control where orders are given and obeyed and performance is closely monitored; (2) bureaucratic control where people are assigned to specialized roles (tasks), which they perform under looser supervision; and (3) control of the premises of decision making where "the subordinate restricts the range of stimuli that will be attended to ... and the range of alternatives that would be considered" (Perrow 1986: 129).

A notable feature of modern industrial corporations was the fact that managers, sometimes through intermediaries such as foremen, exercised direct, "fully obtrusive" control over the flow of work and the actions of workers. Bosses gave orders and they were obeyed. Under the law, failure to obey a boss' order was grounds for discipline or firing (Masten 1988; Freeland 2016). The question is: What characteristics of a technology make direct control necessary or useful?

I suggest that direct authority is good for three things: (1) synchronization, (2) education, and (3) coercion. Synchronization comes first. Coordinating actions precisely in 
time is a human skill, not found in other animals. But, especially when large numbers are involved, centralized authority is needed both to keep time (think of an orchestra conductor or the coxswain of a crew) and to design and assign the sequence of coordinated actions (think of a choreographer or an engineer laying out an assembly line).

In high-speed processes, any slowdown for consultation or negotiation will undermine the efficiency of the process and may destroy its effectiveness. Furthermore, if the process involves many people, it is useful to have someone outside the synchronized space, who can first determine a feasible and consistent set of actions (the "plan") and then identify points of imbalance (bottlenecks) and redress them. Thus, it is best if direct authority is given to a designated actor (or actors) in advance. (Authority over different aspects of the process can be split up among different actors. Thus, a conductor has authority over the tempo of the performance, while a choreographer has authority over the sequence of actions to be performed. Importantly, these actors exercise their authority at different times.)

Direct authority is also useful when one person knows more than another about the task at hand. A teacher can teach basic tasks and skills by giving orders, observing performance, and providing feedback and correction. When the tasks are programmed and the skills are physical, direct authority is an effective and natural method of instruction. Giving orders can be helpful when a student truly does not know what to do. It is only when trying to teach higher-level skills-e.g., judgment under uncertainty or problem selection-that the instructor needs to forgo direct authority for more indirect and unobtrusive methods of control.

Finally, direct authority can be a means of coercion; of making someone do something, he or she would not choose to do on his or her own. A direct order backed up with enforcement can send someone into danger. It can put someone to work on boring, repetitive tasks. It can direct someone to perform actions that are difficult or unpleasant and have no intrinsic value to the actor.

Given this profile, it is not surprising that some of the earliest and most successful uses of direct authority were in military settings. The Roman legions proved in their time that an infantry subject to direct authority and trained to carry out synchronized actions was militarily superior to loosely coordinated cavalry or disorganized hordes inspired by alcohol and plunder.

In the eighteenth and nineteenth centuries, the principles of an authority hierarchy were carried over to commercial enterprises, beginning with cloth and lace factories, extending to railroads, and then to corporations engaged in mass production, such as steel mills, meatpackers, and automakers (Chandler Jr 1977; Hounshell 1985; Landes 1986; Fields 2004). All of these enterprises depended on synchronization of workflow for safety and efficiency. Their production processes were technologically advanced, and thus beyond the comprehension of most workers (who in any case saw only small parts of the overall system). At the same time, the technologies required workers to carry out precise tasks in a strictly timed order. The tasks themselves were often strenuous, boring, repetitive, and even dangerous.

The step-based flow technologies of the late nineteenth and early twentieth centuries thus met all three criteria for the efficacy of direct authority. In their core production, distribution, and marketing activities, most of the enterprises using the new high-flowthrough technologies were organized as a hierarchy of "bosses" exercising direct 
authority over subordinates. Direct authority, bosses, and modern technology thus came to be seen as inextricably intertwined. ${ }^{13}$ The technological requirements that made this organizational form efficient then faded into the background. It came to be taken for granted that authority was essential to the way modern firms worked.

However, in the late twentieth century, these assumptions were challenged in two ways: first, by the Toyota Production System which showed how flow processes might be managed more productively by engaging workers in a process of continuous improvement; and second, by the increasing importance of non-flow technologies especially in the realm of information goods and software.

\section{The rise of corporations}

Modern corporation law

I have argued that flow rationalization is a technological process that rewards certain organizational choices, specifically the placement of all potential bottlenecks under unified governance, a hierarchical organization structure, and the exercise of direct authority in the design of work and the supervision of workers. Organizations displaying all three attributes became both common and powerful at the turn of the twentieth century.

The law regarding corporations, which took its current form at the end of the nineteenth century, provided a legal framework that supported the organizational attributes demanded by flow technologies. By the 1850s, in most states, businesses organized as corporations had the ability to create zones of property ownership that reflected the interdependencies in the underlying technical processes and could last for indefinite periods of time. In contrast to proprietorships and partnerships, the technical processes carried out within a corporation would not be interrupted by the death or bankruptcy of an owner-they would continue under ownership of the corporation, and only the shares would change hands. ${ }^{14}$ In addition, assets not essential to the technical process could be placed outside the corporation's ownership: if the corporation subsequently failed, those assets could not be seized by the corporation's creditors (limited liability). Finally, beginning in 1889, when New Jersey passed a law permitting holding companies, a corporation's zone of activity could extend across state boundaries. ${ }^{15}$ These were all new and valuable features of corporations relative to the preceding legal forms of business organization.

Legally constituted corporations are intrinsically hierarchical, since all decision rights are ultimately traceable to a single legal "person" whose actions are controlled by a Board of Directors (Blair 2003; Freeland 2016). This kernel of hierarchy could be elaborated into a hierarchical organization through the Board's power of delegation. However, delegated decision rights could be withdrawn at any time-they were "loaned

\footnotetext{
${ }^{13}$ See, for example, the classic Charlie Chaplin film, "Modern Times."

${ }^{14}$ Hansmann et al. (2006) call this feature "asset partitioning."

${ }^{15}$ Before 1889 , states did not allow corporations operate outside their boundaries. Responding to this limitation, in the 1880s, companies in a number of industries combined to form "trusts." When trusts were formed, the entering partnerships had to incorporate so that their owners would have securities to exchange for trust certificates; thus, the trust movement contributed to the rise of corporations. In 1889, New Jersey passed a law that permitted holding companies to own businesses in several states, and in 1890, Congress passed the Sherman Antitrust Act, which made the legality of trust agreements questionable. Thereafter, virtually all large enterprises were legally organized as holding companies. By 1910, corporations were the dominant form of organization for large businesses in the USA. (Navin and Sears 1955).
} 
and not owned" (Baker et al. 1999). Undelegated, residual decision rights were vested in the Board of Directors and could not be transferred without transferring the ownership of shares (Freeland and Zuckerman 2018).

The laws governing the relationship of employers and employees also evolved in ways that confirmed the corporation's direct authority and close control of work processes. Indeed, employment law in the USA and Great Britain derived from prior law governing master-servant relationships (Coase 1937; Atleson 1983; Ahlering and Deakin 2007). In contrast, contract law did not give managers rights of close control over the way contractors performed their work (Coase 1937; Masten 1988; Freeland 2016).

It is no accident that modern corporations have exactly the properties needed to rationalize a multi-step flow process with bottlenecks. There were enormous opportunities to create and capture value by rationalizing the many mechanized flow technologies that were invented in the latter half of the nineteenth century. The limitations of the pre-existing legal forms-mainly proprietorships and partnerships, but also trusts and single-state corporations-could themselves be viewed as another set of bottlenecks reducing the efficiency of these processes. A great deal of money and effort was spent on lobbying state legislators in attempts to address these institutional deficiencies. In the end, the modern corporation emerged as the "winner" in competition with the other legal forms of organization. It was the legal framework actively chosen by the owners of large enterprises as most suited to their goals. Most of the companies that managed step processes began as proprietorships or partnerships, but, by 1917, almost all had opted to become corporations (Berle and Means 1932; Navin and Sears 1955; Navin 1970; Chandler Jr 1977: Appendix A; Rosenberg and Birdzell Jr 2008: 220; Roy 1999).

The legal form was not without its problems and critics, however. In particular, the empowerment of managerial bureaucracies and the increasing separation of ownership from control created opportunities for rent-seeking, risk-shifting, and empire-building on the part of managers. Although the legal form enabled managers to pursue efficiency in flow processes, large corporations were only as efficient as competition required them to be (Berle and Means 1932; Jensen and Meckling 1976; Roe 1991, 1996).

Furthermore, in many corporations, managers abused their rights of close control in service of a theory of machine-like efficiency in production flows. Inside these companies, the right of close control over employees was used both to collect information and to redesign jobs. Systematic and scientific management pointed managers towards defining and assigning tasks in ways that caused deskilling, physical hardship, and devaluation of the workers' decision-making abilities. Distrust, resistance, and outright hostility on the part of workers was the common result (Nelson 1974; Noble 1984; Halberstam 1986; Drucker 1993).

The characteristic response by managers was to resort to authority and to fight any attempt to organize the labor force. Over time, loosely controlled inside contractors were replaced by employees subject to direct authority. Labor organizers were summarily fired. In many companies and industries, a wide gulf opened up between management and an increasingly disaffected workforce. Only later, with the advent of the Toyota Production System and other Japanese organizational innovations, did it become evident that even higher levels of efficiency could be achieved by making workers part of a system aimed at continuous improvement. However, that demonstration lay many decades in the future. 


\section{The corporate headquarters}

The first corporate headquarters in the USA were central units organized by functional departments, i.e., manufacturing, marketing, transportation, and R\&D. There was only one corporate headquarters. For companies that stayed within their primary markets, that structure proved sufficient (Chandler Jr 1962: 47). However, beginning in the 1920 s and continuing through the 1960s, many corporations saw opportunities in product diversification and/or geographic expansion. It quickly became apparent that a single, central headquarters based on functional departments was inadequate to process the information required to manage multi-product and multinational organizations. The central staff and top managers were overwhelmed by the need to understand and set plans for vastly different businesses.

The answer was to split operations into divisions, place departmental staffs under the aegis of a division manager, and create a new central headquarters with responsibility for long-range planning, finance, accounting, and government and public relations. This was the "M-form" of corporation, characterized by two levels of headquarters, divisional and corporate (Chandler Jr 1962; Williamson 1985: 279-284).

The technology of flow rationalization does not explain the scope of multidivisional corporations. Their boundaries are the result of strategies of growth and/or diversification, not the technological need to rationalize complex, time-sensitive step processes. In a multi-divisional corporation, divisions are business units that contain separable processes. Close coordination across divisions is not required to achieve technical efficiency.

Indeed beginning in the 1970 s and 1980s, the cost of central oversight and the resulting overhead burden on the divisions weighed down performance in many large corporations (Jensen 1986, 1989). The stand-alone value of a division, freed from central oversight and uniform policies, might be greater than its contribution to the parent corporation. Such divisions became targets of divestiture and candidates for organization redesign as leveraged buyouts (LBOs).

\section{Conclusions}

In summary, wherever they arise, step processes with capacity constraints are vulnerable to randomly occurring production bottlenecks. Systematic management is essential to addressing and eliminating these bottlenecks, and thus making these processes efficient. In this paper, I have combined theories of organization design and production and argued that the need to rationalize complex flows of goods provided the technological impetus for the creation of modern industrial corporations with centralized corporate headquarters. Consistent with the need to coordinate flows of goods and information, the original corporate headquarters were organized along functional lines that corresponded to the stages of the underlying step processes (purchasing, manufacture, marketing, distribution) and improving the processes through the elimination of bottlenecks (engineering, $R \& D$ ). In this way, the technological demands of flow rationalization set the stage for the emergence of the first modern corporate headquarters. 
Author's contributions

The author declares that she is the sole author of this article. The author read and approved the final manuscript.

\section{Funding}

The author gratefully acknowledges the support of Harvard Business School Division of Research and Faculty Development in funding this research.

\section{Availability of data and materials}

The data used in this article consists of historical accounts listed in the references. All such accounts are publicly available.

\section{Competing interests}

The author declares that she has no competing interests.

Received: 18 October 2018 Accepted: 4 October 2019

Published online: 23 October 2019

\section{References}

Ahlering B, Deakin S (2007) Labor regulation, corporate governance, and legal origin: a case of institutional complementarity? Law Soc Rev 41(4):865-908

Atleson JB (1983) Values and assumptions in American labor law. University of Massachusetts Press, Boston

Baker G, Gibbons R, Murphy KJ (1999) Informal authority in organizations. J Law Econ Org 15(1):26-73

Baldwin CY (2018a) Complementarity. Harvard Business School Working Paper (October 2018)

Baldwin CY (2018b) The value structure of technologies, part 1: mapping functional relationships. Harvard Business School Working Paper (October 2018)

Baldwin CY (2018c) The value structure of technologies, part 2: technical and strategic bottlenecks as guides for action. Harvard Business School Working Paper (October 2018)

Baumol WJ (2002) The free-market innovation machine. Princeton University Press, Princeton

Berle AA, Means GC (1932) The modern corporation and private property. Transaction Publishers, New Brunswick Birkinshaw JM (2018) How is technological change affecting the nature of the corporation? J Br Acad 6(s1):185-214

Blair MM (2003) Locking in capital: what corporate law achieved for business organizers in the nineteenth century. UCLA Law Rev 51(2):387-455

Chandler AD Jr (1962) Strategy and structure. MIT Press, Cambridge

Chandler AD Jr (1977) The visible hand: the managerial revolution in American business. Harvard University Press, Cambridge

Chandler AD Jr (1985) The standard oil company - combination, consolidation, and integration. In: Chandler AD Jr, Tedlow RS (eds) The coming of managerial capitalism: a casebook on the history of American economic institutions. Richard D. Irwin, Homewood, pp 343-371

Chandler AD Jr (1986) The beginnings of the modern industrial corporation. Proc Am Philos Soc 130(4):382-389

Chandler AD Jr (1990) Scale and scope: the dynamics of industrial capitalism. Harvard University Press, Cambridge

Coase RH (1937) The nature of the firm. Economica 4(16):386-405

da Silva LT, Casson M, Jones G (2018) Organizational innovation in the multinational enterprise: internalization theory and business history. J Int Bus Stud 50(8):1338-1358

Drucker PF (1993) Concept of the corporation (1st edition 1946). Transaction Publishers, New Brunswick

Fields G (2004) Territories of profit: communications, capitalist development, and the innovative enterprises of G.F. Swift and Dell Computer. Stanford University press, Stanford

Freeland RF (2016) The employment relation and Coase's theory of the firm. In: Menard C, Bertrand E (eds) The Elgar Companion to Ronald H. Coase. Edward Elgar, Northampton

Freeland RF, Zuckerman E (2018) The problems and promise of hierarchy: voice rights and the firm. Sociol Sci 5(7):143-181

Fukuyama F (1995) Trust: the social virtues and the creation of prosperity. Free Press, New York

Galbraith JK (1967) The new industrial state. Houghton Mifflin, Boston

Halberstam D (1986) The reckoning. William Morrow, New York

Hansmann H, Kraakman RH, Squire R (2006) Law and the rise of the firm. Harvard Law Rev 119(5):1335-1403

Harry MJ, Schroeder RR (2005) Six Sigma: the breakthrough management strategy revolutionizing the world's top corporations. Broadway Business, New York

Hart O, Moore J (1990) Property rights and the nature of the firm. J Polit Econ 98(6):1119-1158

Hounshell DA (1985) From the American system to mass production, 1800-1932. Johns Hopkins University Press, Baltimore Jacobides MG, Cennamo C, Gawer A (2018) Towards a theory of ecosystems. Strateg Manag J 39(8):2255-2276

Jaikumar R, Bohn RE (1986) The development of intelligent systems for industrial use: a conceptual framework. In:

Rosenbloom RS (ed) Research on technological innovation, management and policy, vol 3. JAI Press, Greenwich Jensen MC (1986) Agency costs of free cash flow, corporate finance, and takeovers. Am Econ Rev 76(2):323-329 Jensen MC (1989) Active investors, LBOs, and the privatization of bankruptcy. J Appl Corporate Financ 2(1):35-44 Jensen MC, Meckling WH (1976) Theory of the firm: managerial behavior, agency costs, and ownership structure. J Financ Econ 3(4):305-360

Kaplan ADH (1964) Big enterprise in a competitive system. The Brookings Institution, Washington

Kendall HP (1912) Types of management: unsystematized, systematized, and scientific. In: Dartmouth College Conferences, Addresses and Discussions at the Conference on Scientific Management, pp 112-141 Available at https://books.google. com/books

Landes DS (1986) What do bosses really do? J Econ Hist 46(3):585-623

Landes DS (1998) Wealth and poverty of nations. W.W. Norton, New York

Landes DS (2003). The unbound Prometheus: technological change and industrial development in Western Europe from 1750 to the present. Cambridge University Press, Cambridge. 
Litterer JA (1963) Systematic management: design for organizational recoupling in American manufacturing firms. Business Hist Rev 37(4):369-391

Marx L (1994) The idea of "technology" and postmodern pessimism. In: Smith MR, Marx L (eds) Does technology drive history: the dilemma of technological determinism. MIT Press, Cambridge

Masten SE (1988) A legal basis for the firm. J Law Econ Organization 4(1):181-198

Menz M, Kunisch S, Collis DJ (2015) The corporate headquarters in the contemporary corporation: advancing a multimarket firm perspective. Acad Manag Ann 9(1):633-714

Milgrom P, Roberts J (1990) The economics of manufacturing: technology, strategy and organization. Am Econ Rev 80(3): $511-528$

Milgrom P, Roberts J (1995) Complementarities and fit strategy, structure, and organizational change in manufacturing. J Account Econ 19(2):179-208

Navin TR (1970) The 500 largest American industrials in 1917. Business Hist Rev 44(3):360-386

Navin TR, Sears MV (1955) The rise of a market for industrial securities, 1887-1902. Business Hist Rev 29(2):105-138

Nelson D (1974) Scientific management, systematic management, and labor, 1880-1915. Business Hist Rev 48(4):479-500

Noble DF (1984) Forces of production: a social history of industrial automation. Oxford University Press, Oxford

Perrow C (1986) Complex organizations: a critical essay. McGraw Hill, New York

Popplewell F (1906) Some modern conditions and recent developments in iron and steel production in America. Sherratt \& Hughes, Manchester

Roe MJ (1991) A political theory of American corporate finance. Columbia Law Rev 91(1):10-67

Roe MJ (1996) Strong managers, weak owners: the political roots of American corporate finance. Princeton University Press, Princeton

Rosenberg N, Birdzell LE Jr (2008) How the West grew rich: the economic transformation of the industrial world. Basic Books, New York

Rothschild M, Stiglitz JE (1970) Increasing risk: I. A definition. J Econ Theory 2(3):225-243

Roy WG (1999) Socializing capital: the rise of the large industrial corporation in America. Princeton University Press, Princeton Schumpeter JA (1942) Capitalism, socialism, and democracy. Harper \& Brothers, New York

Servan-Schreiber JJ (1968) The American challenge. Atheneum, New York

Shenhav Y (1995) From chaos to systems: the engineering foundations of organization theory, 1879-1932. Adm Sci Q 40(4): $557-585$

Simon HA (1951) A formal theory of the employment relationship. Econometrica 19(3):293-305

Smith A (1994) An inquiry into the nature and causes of the wealth of nations. Modern Library, New York

Sturgeon TJ (2002) Modular production networks: a new American model of industrial organization. Ind Corp Chang 11(3): $451-496$

Temin P (1964) Iron and steel in nineteenth-century America: an economic inquiry. MIT Press, Cambridge

Thompson JD (1967) Organizations in action: social science bases of administrative theory. McGraw-Hill, New York

Williamson OE (1985) The economic institutions of capitalism. Free Press, New York

\section{Publisher's Note}

Springer Nature remains neutral with regard to jurisdictional claims in published maps and institutional affiliations.

\section{Submit your manuscript to a SpringerOpen ${ }^{\circ}$ journal and benefit from:}

- Convenient online submission

- Rigorous peer review

- Open access: articles freely available online

- High visibility within the field

- Retaining the copyright to your article

Submit your next manuscript at $\boldsymbol{\nabla}$ springeropen.com 